
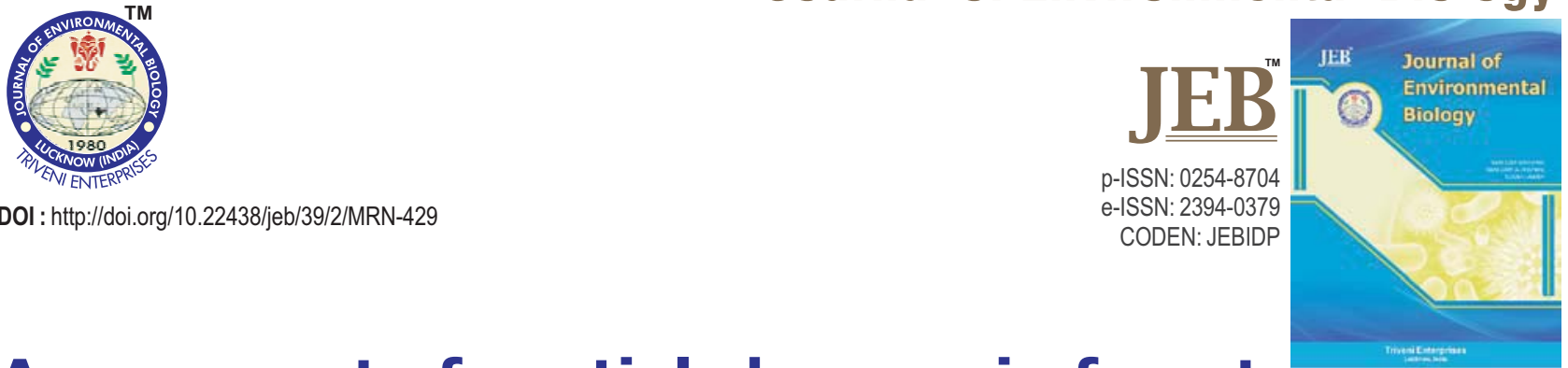

\title{
Assessment of spatial changes in forest cover and deforestation rate in Eastern Ghats Highlands of Odisha, India
}

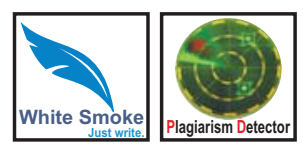

Authors Info

Ch. J. Dash', P.P. Adhikary", M. Madhu', S. Mukhopadhyay', S.K. Singh ${ }^{2,3}$ and P.K. Mishra ${ }^{4}$

'ICAR-Indian Institute of Soil and Water Conservation, Research Centre, Koraput-763 002, India

${ }^{2}$ ICAR-National Bureau of Soil Survey and Land Use Planning, Regional Centre, Kolkata-700 091, India

${ }^{3}$ ICAR-National Bureau of Soil Survey and Land Use Planning, Nagpur-440 033, India

${ }^{4}$ ICAR-Indian Institute of Soil and Water Conservation, Dehradun-248 195, India

${ }^{*}$ Corresponding Author Email : partha.adhikary@icar.gov.in

Key words

Deforestation

Forest cover

Forest fragmentation

GIS

Remote sensing

Publication Info

Paper received: 05.08.2016

Revised received: 16.12.2016

Re-revised received: 19.04.2017

Accepted:08.08.2017

\section{Abstract}

Aim : The spatial changes in forest cover and deforestation rate over eight decades in Koraput district of Odisha, a mountainous part of Eastern Ghats Highland region was studied using remote sensing and GIS. The dynamics of forest fragmentation was also quantified using patch analysis.

Methodology : The multi-source and multi-date mapping was carried out using Survey of India topographical maps (1930's), Landsat MSS (1973), Landsat TM (1990), IRS P6 LISS III (2004 and 2013) satellite images. Radiometric and contrast correction was done to the images using digital image processing software. On-screen visual interpretation of forest cover was done which was aided by unsupervised classification. Ground truthing was done to determine the classification accuracy. Patch analysis was done to quantify forest fragmentation.

Results : The mapping accuracy varied between $71.8 \%$ and $93.3 \%$ for different years under study. The results for 1932, 1973, 1990, 2004 and 2013 indicate that the forest cover for the mentioned years were $4413.4 \mathrm{~km}^{2}, 3706.0 \mathrm{~km}^{2}, 3051.1 \mathrm{~km}^{2}, 2554.4 \mathrm{~km}^{2}$ and $2284.5 \mathrm{~km}^{2}$, which were $52.7 \%, 44.2 \%, 36.4 \%, 27.3 \%$ and $25.8 \%$ of the geographical area of the district, respectively. The deforestation rate was $0.38 \%$ per year during 1932-1973, 2.04\% per year during $1973-1990,1.71 \%$ per year during 1990-2004 and $0.63 \%$ per year during 2004-2013. The decline in overall rate of deforestation in recent years indicates increased emphasis on forest conservation. The number of fragmented forest patches was 398 in 1932, 645 in 1973, 688 in 1990, 697 in 2004 and 702 in 2013, which indicates ongoing anthropogenic pressure on the forests. The mean forest patch size decreased from $111 \mathrm{~km}^{2}$ in 1932 to $65.8 \mathrm{~km}^{2}$ in 2013.

Interpretation : This study indicates the effectiveness of

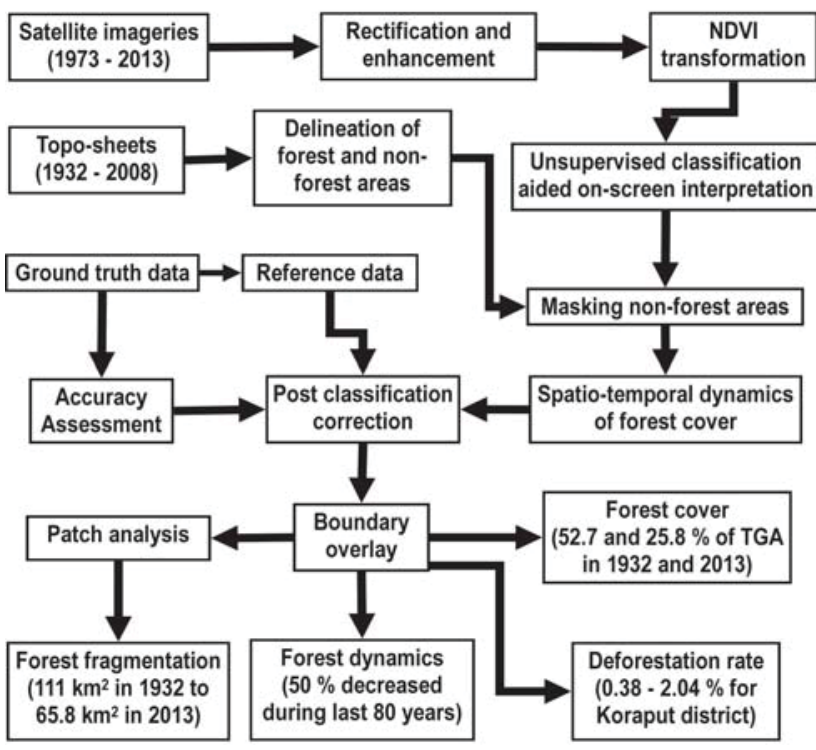
remote sensing in indentifying the forest and non-forest area. The change analysis of deforestation provides a decisive component for conservation and helpful in long term rational management of the remaining forests of the district for ecorestoration and sustainable development. 


\section{Introduction}

Natural forests are one of the most important terrestrial ecosystems of the earth, and are of great interest due to conservation of biodiversity, apart from global carbon cycle. They currently occupy 4.033 billion ha, which is about $31 \%$ of the earth's land surface (FAO, 2010). The human population has increased its ability to manipulate the earth surface mainly because of its increased economic activity (FAO, 2012). This manipulation is most evident in clearing of forests. Clearing of forests (deforestation) to use the land for other purposes, or keeping it as unused wasteland, is very rampant on the surface of the earth. Rapid population growth and the burgeoning demand for food, fodder, fiber and fuel have accelerated the deforestation rate. The world wise average net loss of forest between 2000 and 2010 has reached about 5.2 million ha per year (FAO, 2010). Deforestation has impact on biodiversity, carbon stock, soil, global climatic systems and livelihoods of dependent people, and hence is reason for concern. Although the deforestation rates have been reduced in many parts of the world, but it is still more than $0.1 \%(0.36 \%)$ per year in SoutheastAsian countries (FAO, 2010).

Factors affecting deforestation vary widely, within and among countries. According to the Forest Survey of India (FSI) report, in India over 2.62 million ha of forest was lost due to agricultural expansion between 1951 and 1980 (FSI, 1988). This continued with the loss of forest cover of $1,88,900$ ha per year between 1991 and 1999 (FSI, 2000). However, forest cover in India has more or less stabilized after 1980 due to ban on clear felling (Reddy et al., 2009; FSI, 2013). In recent times, between 2001 and 2013 there was also increase in forest area from 67.55 million ha to 69.79 million ha (FSI, 2013).

Most of the deforestation studies in India have been given priority to the biodiversity rich areas such as North-East India (Roy and Joshi, 2002; Lele and Joshi, 2009), Western Ghats (Jha et al., 2000; Krishnaswamy et al., 2004) and Andaman and Nicobar islands (IIRS, 2002). Few studies have been conducted in the Eastern Ghats (Sakthivel et al., 2010; Reddy et al., 2014) region. Most of the studies are focused on mapping vegetation communities, generating data on biodiversity and prioritizing the areas for bio-prospecting. In a study, Reddy et al. (2009) mapped the forest cover change in Nabarangapur district of Odisha during 1978-2005. Similarly, Harikrishna et al. (2014) has analysed the forest cover change in Andhra Pradesh and reported the occurance of large scale deforestation during 1930-1975 period. The deforestation rates, drivers of deforestation and the Government initiatives for conservation of forests in India were summarized by Reddy et al. (2013b). The effectiveness of conservation measures under the ongoing forest management practices in Nilgiri biosphere reserve has been well documented by Satish et al. (2014). For determination of long period forest change, long term datasets need to integrate data from large scale historical topographical maps and recent remote sensing datasets.
Remote sensing techniques using satellite images are the most effective and common data source for detection, quantification, and mapping of forest areas and its changes over time (Sakthivel et al., 2010), because of its repetitive data acquisition, digital format suitable for computer processing, and accurate geo-referencing procedures. Besides, it provides information to help to resolve controversies about future management directions (Kumar et al., 2014). The present study was undertaken to investigate the historical changes that have taken place in forest land in southern parts of Odisha, India. This area is known for extensive shifting cultivation and have degraded due to soil erosion (Adhikary et al., 2017). It is believed that this aggressive human activity might have influenced the forest, resulting in a possible impact on the environment. Therefore, the objectives of this study included quantification of recent and historical forest land of the study area through integration of supervised classification, visual interpretation of remote sensing data, use of topographical sheets, and to assess the rate of change in forest cover and forest fragmentation over the time.

\section{Materials and Methods}

Study area : The study was carried out in Koraput district of Odisha, a mountainous part of Eastern Ghats Highland region of India, consists of many valleys with scrub and/or deciduous forests on the upper slopes. The study area lies between $82^{\circ} 05^{\prime}$ to $83^{\circ} 25^{\prime} \mathrm{E}$ longitude and $18^{\circ} 14^{\prime}$ to $19^{\circ} 13^{\prime} \mathrm{N}$ latitude (Fig. 1), covering an area of $8379 \mathrm{~km}^{2}$. It is situated at elevation varying between 123 and $1655 \mathrm{~m}$ above mean sea level. The district Koraput is popularly known as the land of aboriginals and is one of the global biodiversity hotspots (Raut et al., 2012). It has subtropical climate with mean maximum and minimum temperature of $35.8{ }^{\circ} \mathrm{C}$ and $7.6^{\circ} \mathrm{C}$ and mean annual precipitation of $1452 \mathrm{~mm}$ (Adhikary et al., 2015). The soils of the study area were been identified as Alfisols and Inceptisols (NBSSLUP, 2005), and both soil depth and texture varied with the topography and become less favourable for cultivation with increasing slope steepness. The hills and hill slopes were mostly dominated by light yellow to brown soils, whereas red sandy to loamy soils were found in the foothills and uplands.

The natural conditions of the district favour a good growth of dry miscellaneous, Bamboo and Sal forests and allow a rich diversity of fauna and flora. However, due to human interference, the vegetation shows severe signs of degradation, and forest cover has declined within the last decades (FSI, 2013). Agricultural practices extend from valley bottom to hilltop, with variety of cropping systems and management practices. The livelihood practices consisted of activities like timber collection, shifting cultivation, permanent agriculture, mining, etc. The practice of shifting cultivation (called podu chasa in local language) is one of the major cause behind deforestation, resulting in conversion of dense forests to open forests as well as degraded forests. 
Data and assessment periods : The data used in this study include both Survey of India (SOI) topographic sheets and multidate satellite images (Table 1). The forest cover map for the year 1932 was developed using topographic sheets. For other years satellite images such as Landsat MSS (path-151/152 and row-47) for 1973, Landsat TM (path-141/142 and row-47) for 1990, IRS P6 LISS III (path-103 and row-59; path-104 and row-59/60) for 2004 and 2013 were used. The SOI topographic maps of 2008 (scale 1:50,000) were digitized and used for preparing base map and ground truthing after geo-referenced. Finally, during April-May, 2014, a total of 1000 ground truth points were collected from the study area.

Image enhancement, visual interpretation and classification : In this study, ERDAS Imagine 9.2 software was used for digital image processing of satellite images (ERDAS, 2008). First contrast stretching was applied on images to enhance the visual interpretation capability. Prior to image classification, land use features were categorized into four types: dense forest, open forest, non-forest, and water bodies. These four types were identified based on the visual interpretation of satellite imagery on the basis of tone, texture, shape, pattern and association etc. and verified from field inspection. Training samples were then selected for each of the three land use types by delimiting polygons around representative sites. Using the pixels enclosed by these polygons, spectral signatures for the respective land use recorded by the satellite images were derived. Once the spectral signature was deemed satisfactory, the classification process executed, and in this study supervised maximum likelihood method was used as classification method. Finally, accurate forest land use maps were compared with the reference data (the topographic maps, and ground trust points) to assess the classification accuracy.

Classification accuracy assessment : A classification accuracy assessment was performed based on 1000 random points that were identified and located using a random method in ERDAS software to represent the different land use classes of the area. The 1000 points used in the study represented field checkpoints (ground truth data), archived data and topographic maps as reference data. The reference data and the classification results were compared and statistically analyzed using error matrices.

Deforestation rate analysis : Maps were analyzed to identify the magnitude of change. Deforestation rate for successive years of forest cover mapping was evaluated using equation given by Armenteras et al. (2006).

Forest fragmentation through landscape matrix : Patch analysis was done using Arc GIS and MS EXCEL spreadsheet. Four landscape matrices were selected and analyzed. (i) Number of patches: It is the number of patches for any particular size class. It measures the extent of fragmentation of the entire landscape. (ii) Patch density: It expresses the number of patches per unit area basis that facilitates comparisons among landscapes of varying size. Patch density can be calculated by the number of patches in the landscape, divided by total landscape area. (iii) Mean patch size: It is the average patch size within a particular class, or at the landscape level, the average size of all classes. Habitat fragmentation index can be measured through mean patch size. (iv) The largest patch index : It is the measure of the percentage of landscape area occupied by the largest patch of a class.

\section{Results and Discussion}

The accuracy of classification results derived from satellite images for change detection of forest cover were verified by creating an error matrix. The generated error matrix is given in Table 2. The classification accuracy for the classified images for the years 1973, 1990, 2004 and 2013 were $71.8 \%, 85.2 \%, 90.7 \%$ and $93.3 \%$, respectively. Forest cover change is a dynamic process and it changes both spatially and temporally. It is ascertained through time series analysis that there has been a significant change in the forest cover, particularly the conversion of dense forest to open forest and other land uses (non-forest).

Assessment period I : 1932-1973 : The developed forest classes using satellite images such as dense forest and open forest do not find place in the 1930's topographic sheet; instead only the symbols representing the trees are given. Moreover, in the topographic sheets the forest are classified as reserve forest and mixed forest. Hence, because of the varied classification adopted in the topographic sheets and satellite images, it is not possible to compare the forest classes given in these two data sets, readily. Therefore, the total area under forest cover for the assessment period I was compared. In 1932, area under reserve forest was $2786.2 \mathrm{~km}^{2}$ and area under mixed forest was 1627.3 $\mathrm{km}^{2}$, which were $33.3 \%$ and $19.4 \%$ of the study area, respectively. The total area under forest was $4413.5 \mathrm{~km}^{2}$, which was $52.7 \%$ of the study area (Table 3). In 1973, area under dense forest was $2584.7 \mathrm{~km}^{2}$ and area under open forest was $1121.3 \mathrm{~km}^{2}$, which were $30.8 \%$ and $13.4 \%$ of the study area, respectively. The total forest cover was reduced to $3706.0 \mathrm{~km}^{2}$, which was $44.2 \%$ of the study area (Table 3). The deforestation rate in the Koraput district was found to be $0.38 \%$ per year for the assessment period I (Fig. 2). Deforestation in the study area started mainly after independence of India because of infrastructure development, construction of dams and population pressure (Reddy et al., 2013a). Encroachment on forest lands and converting them in to cultivated area by shifting cultivation played a significant role in deforestation for the period I (Dash, 2006). The areas where changes have taken place are hilly terrains with relatively less slope and easily accessible to villages nearby; whereas the forest cover patches are intact at places where the terrains are inaccessible owing to difficult terrain conditions and high altitude. Other causes behind forest cover changes are illegal timber cutting and extraction of other forest resources. Although, the deforestation rate during the assessment period I was high but that was much lower than the deforestation rate observed in the adjoining Andhra Pradesh state. During same period, the deforestation rate in Andhra Pradesh was 1.62\% per year 
(Harikrishna et al., 2014) which was attributed to the increased anthropogenic pressure on the forest lands.

Assessment period II : 1973-1990 : Between 1973 and 1990, there was also a reduction in the dense forest cover to about $1615.8 \mathrm{~km}^{2}$ (19.3\%). However, there was increase in open forest area $\left(1285.4 \mathrm{~km}^{2}\right)$ during this period, indicating degradation of dense forest to open forest. Though there was increase in open forest cover, the results indicated that there was an overall reduction of $804.5 \mathrm{~km}^{2}$ of forest cover, which was $9.6 \%$ of the total geographical area of the district (Table 3). The non-forest area increased from $4579.0 \mathrm{~km}^{2}(54.6 \%)$ to $5333.4 \mathrm{~km}^{2}(63.7 \%)$ in 1990. Considerable increase in the area of water body (94 to $144.4 \mathrm{~km}^{2}$ ) was also observed during this period. The deforestation rate was found to be $3.92 \%$ per year for dense forest, and the overall deforestation rate was $2.04 \%$ per year (Fig.
2). While comparing deforestation rate during period I and II, it was observed that deforestation rate during period II was about 5 times more than that of period I. The reasons may be attributed to the developmental works, shifting cultivation and dam construction. During that period Upper Kolab and Lower Kolab multipurpose dams were constructed to increase the irrigation facilities, which ultimately inundated vast amount of forest land and enhanced the conversion of forest land to agricultural land. The deforestation rate during this period was higher than the other forested area in India. Jha et al. (2000) studied the changes in forest cover between 1973 and 1995 in the southern part of the Western Ghats using satellite data that showed rate of net deforestation as $1.34 \%$ per year over 22 years. The authors have accounted for the decrease in forest area due to increase in spatial extent of plantations and agricultural fields (Jha et al., 2000). In the northern Western Ghats region of

Table 1 : Topographical maps and satellite imageries used in the study

\begin{tabular}{llll}
\hline Type & Period & Scale / Resolution* & Source \\
\hline SOI topographical maps & $1930-1935$ & $1: 2,50,000$ and 1"=1 mile & US Army Map Service and SOI, Dehradun \\
Landsat MSS & 1973 & $80 \mathrm{~m}$ & GLCF \\
Landsat TM & $1989-1990$ & $30 \mathrm{~m}$ & GLCF \\
IRS P6 LISS-III & 2004 & $23.5 \mathrm{~m}$ & NRSC \\
IRS P6 LISS-III & 2013 & $23.5 \mathrm{~m}$ & NRSC \\
\hline
\end{tabular}

*Scale for topographic maps, and spatial resolution for satellite images

Table 2 : Error matrices and total classification accuracy including producer accuracy and user accuracy for the classified images

\begin{tabular}{|c|c|c|c|c|c|c|c|c|}
\hline \multirow{2}{*}{$\begin{array}{l}\text { Reference } \\
\text { data }\end{array}$} & \multicolumn{5}{|c|}{ Land use classes } & \multicolumn{2}{|c|}{$\begin{array}{c}\text { Classification accuracy } \\
(\%)\end{array}$} & \multirow{2}{*}{$\begin{array}{l}\begin{array}{l}\text { Kappa } \\
\text { statistics }\end{array} \\
\left(\mathrm{K}^{\wedge}\right)\end{array}$} \\
\hline & & $\begin{array}{l}\text { Dense } \\
\text { forest }\end{array}$ & $\begin{array}{l}\text { Open } \\
\text { forest }\end{array}$ & $\begin{array}{l}\text { Non } \\
\text { forest }\end{array}$ & $\begin{array}{l}\text { Water } \\
\text { bodies }\end{array}$ & $\begin{array}{l}\text { Producer } \\
\text { accuracy }\end{array}$ & $\begin{array}{l}\text { User } \\
\text { accuracy }\end{array}$ & \\
\hline \multirow{5}{*}{$\begin{array}{l}1973 \\
\text { classified } \\
\text { data }\end{array}$} & Dense forest & 76 & 14 & 7 & 3 & 73.8 & 76.0 & 0.44 \\
\hline & Open forest & 17 & 59 & 17 & 4 & 64.8 & 60.8 & 0.33 \\
\hline & Non forest & 6 & 11 & 64 & 12 & 66.7 & 68.8 & 0.34 \\
\hline & Water bodies & 4 & 7 & 8 & 81 & 81.0 & 81.0 & 0.45 \\
\hline & Total accuracy & & & & & \multicolumn{2}{|c|}{71.8} & 0.67 \\
\hline \multirow{5}{*}{$\begin{array}{l}1990 \\
\text { classified } \\
\text { data }\end{array}$} & Dense forest & 192 & 17 & 19 & 0 & 86.1 & 84.2 & 0.84 \\
\hline & Open forest & 21 & 164 & 14 & 0 & 82.0 & 82.4 & 0.78 \\
\hline & Non forest & 4 & 12 & 178 & 10 & 82.0 & 87.3 & 0.79 \\
\hline & Water bodies & 6 & 7 & 6 & 135 & 93.1 & 87.7 & 0.89 \\
\hline & Total accuracy & & & & & & & 0.84 \\
\hline 2004 & Dense forest & 283 & 11 & 9 & 0 & 92.8 & 93.4 & 0.92 \\
\hline classified & Open forest & 18 & 242 & 19 & 0 & 86.4 & 86.7 & 0.85 \\
\hline \multirow[t]{3}{*}{ data } & Non forest & 4 & 13 & 237 & 0 & 87.8 & 93.3 & 0.86 \\
\hline & Water bodies & 0 & 14 & 5 & 145 & 100.0 & 88.4 & 1.00 \\
\hline & Total accuracy & & & & & \multicolumn{2}{|c|}{90.7} & 0.90 \\
\hline 2013 & Dense forest & 291 & 8 & 15 & 0 & 95.4 & 92.7 & 0.95 \\
\hline classified & Open forest & 12 & 254 & 10 & 0 & 90.7 & 92.0 & 0.90 \\
\hline \multirow{3}{*}{ data } & Non forest & 2 & 11 & 243 & 0 & 90.0 & 94.9 & 0.89 \\
\hline & Water bodies & 0 & 7 & 2 & 145 & 100.0 & 94.2 & 1.00 \\
\hline & Total accuracy & & & & & \multicolumn{2}{|c|}{93.3} & 0.93 \\
\hline
\end{tabular}


Table 3 : Total area and area-wise changes of different land use classes from 1932 to 2013 in Koraput district

\begin{tabular}{|c|c|c|c|c|c|c|c|c|c|c|}
\hline \multirow[t]{2}{*}{ Land use class } & \multicolumn{5}{|c|}{ Total area $\left(\mathrm{km}^{2}\right)$} & \multicolumn{5}{|c|}{ Area (\%) } \\
\hline & 1932 & 1973 & 1990 & 2004 & 2013 & 1932 & 1973 & 1990 & 2004 & 2013 \\
\hline Dense forest & 2786.2 & 2584.7 & 1615.8 & 1109.1 & 964.7 & 33.3 & 30.9 & 19.3 & 13.2 & 11.6 \\
\hline Open forest & 1627.3 & 1121.3 & 1285.4 & 1175.3 & 1193.8 & 19.4 & 13.4 & 15.3 & 14.0 & 14.2 \\
\hline Water body & 75.0 & 94.0 & 144.4 & 196.2 & 201.7 & 0.9 & 1.1 & 1.7 & 2.3 & 2.4 \\
\hline Non forest & 3890.5 & 4579.0 & 5333.4 & 5898.4 & 6018.8 & 46.4 & 54.6 & 63.7 & 70.5 & 71.8 \\
\hline Total & 8379.0 & 8379.0 & 8379.0 & 8379.0 & 8379.0 & 100.0 & 100.0 & 100.0 & 100.0 & 100.0 \\
\hline
\end{tabular}

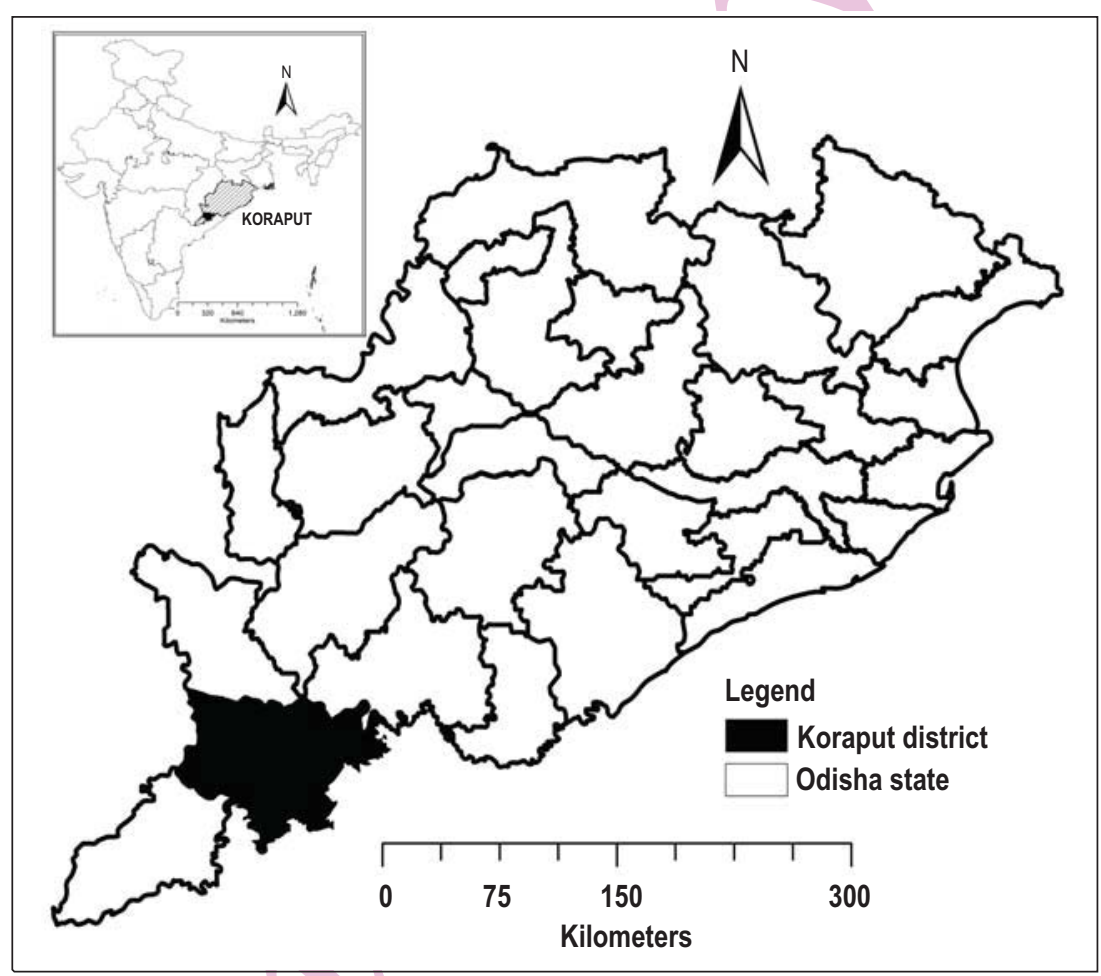

Fig. 1 : Location map of the study area (Koraput district of Odisha, India)

Maharastra, the deforestation rate was nearly $0.37 \%$ per year (Panigrahy et al., 2010).

Assessment period III : 1990-2004 : During this period, there was also a reduction in the dense forest cover to about 1109.1 $\mathrm{km}^{2}(13.2 \%)$. In case of open forest, decreasing trend was also observed. Area under open forest decreased to $1175.3 \mathrm{~km}^{2}$ $(14.0 \%)$. There was an overall reduction of $616.7 \mathrm{~km}^{2}$ of forest cover, which was $7.4 \%$ of the total geographical area. The nonforest area increased from $5333.4 \mathrm{~km}^{2}(63.7 \%)$ to $5898.4 \mathrm{~km}^{2}$ (70.4\%) during 1990-2004 (Table 3). The deforestation rate was found to be $2.69 \%$ per year for dense forest, and the overall deforestation rate was $1.71 \%$ per year (Fig. 2). During the assessment period III, the deforestation rate in Koraput was found to slow down a little but still remained higher than many parts in India. During 1973-2004, in the neighbor district, Malkangiri, the net rate of deforestation was $1.83 \%$ per year (Pattanaik et al., 2011). Various factors with varying intensities like over-grazing, illegal encroachments, unsustainable cultivation practices, forest fires, shifting cultivation and indiscriminate logging were responsible for the ongoing deforestation. In another adjoining district, Nawarangpur, the net and gross rate of deforestation was 3.2 and $4.11 \%$ per year, respectively during the period 1973 to 2004 (Reddy et al., 2009). The main causes of forest change were identified as encroachment for agriculture and settlements, illegal logging, construction of multipurpose dams and other infrastructure development. Another study in R.V. Nagar range, Visakhapatnam, Andhra Pradesh during 1988 to 2006 showed a net deforestation rate of $0.81 \%$ per year and a gross 


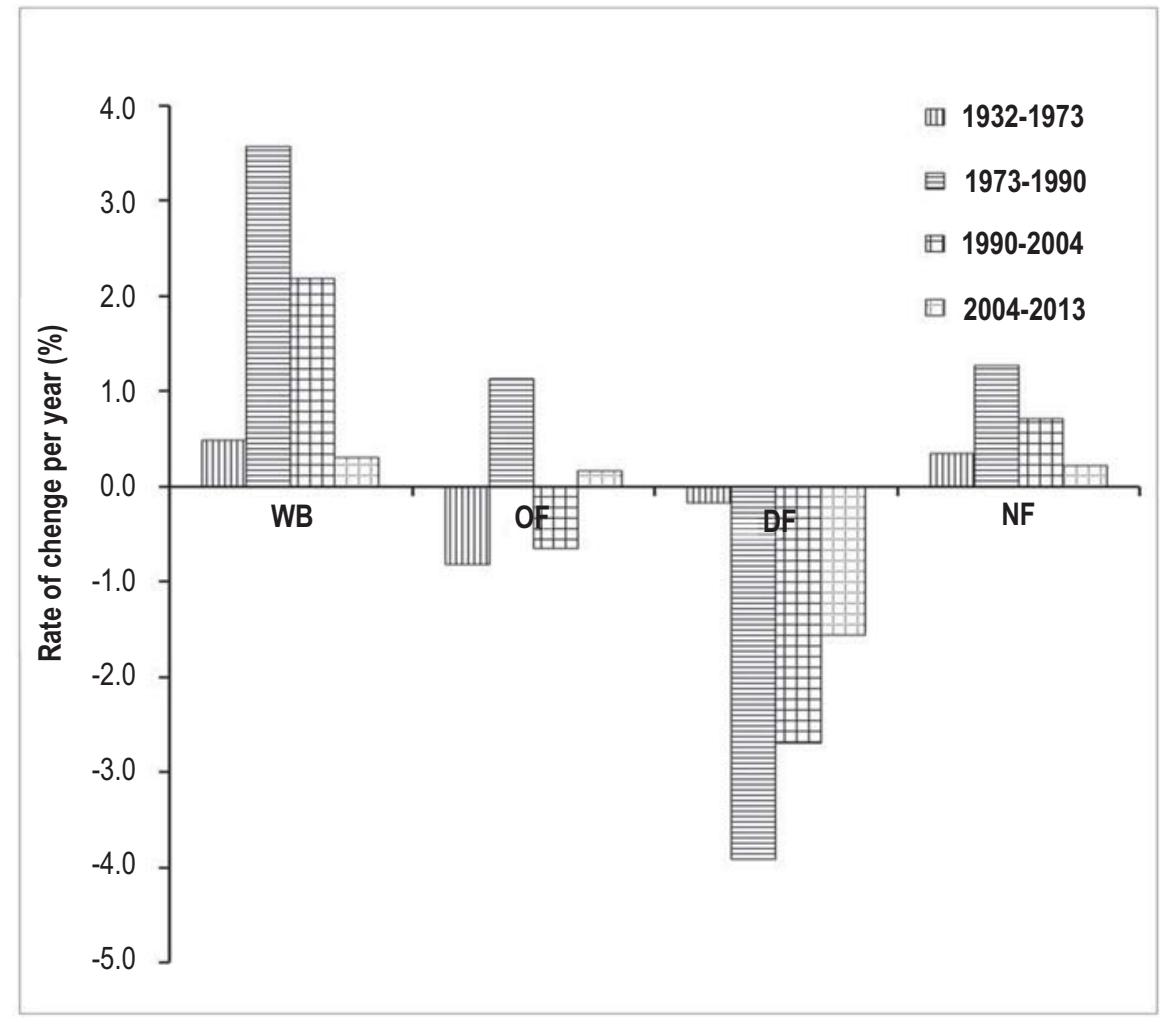

Fig. 2 : Rate of land use changes in Koraput district during the four assessment periods. WB: Water bodies; OF: Open forest; DF: Dense forest; NF: Non-forest

deforestation rate of $1.04 \%$ per year (Reddy et al., 2010). Anthropogenic activities, mainly shifting cultivation and expansion of agricultural fields were identified as driving force for deforestation in that area.

Assessment period IV: 2004-2013 : During the last decade (2004-2013) the deforestation rate was slower than the previous two assessment periods which was $0.63 \%$ per year. There was a loss of $144.4 \mathrm{~km}^{2}$ dense forest area during this period; however, there was an increase in open forest area, indicating conversion of dense forest to open forest and other land uses. Total area under deforestation was found to be $125.9 \mathrm{~km}^{2}$ (Table 3). Although the deforestation rate during the assessment period IV showed a decreasing trend $(0.63 \%$ per year) still it was higher than the national average (FSI, 2013). The cause may be attributed to awareness among the people, and initiative taken by the state forest department, Odisha, to protect and manage the forest land. The result of the present study was in close proximity of another study focusing on the monitoring of deforestation in Ranchi, Jharkhand. It was found that from 1996 to 2008, the net rate of deforestation was $0.95 \%$ per year mainly due to urbanization (Kumar etal., 2010).

Forest fragmentation through patch analysis : In order to estimate the level of isolation of forest fragmentation, patch analysis was done. The forest patches were categorized under seven classes, i.e. <1, 1-5, 5-10, 10-20, 20-50, $50-100$ and $>100 \mathrm{~km}^{2}$ (Table 4) and the number of forest patches falling under each class across the spatial extend of forest cover was analysed. During 1932, out of 398 forest patches, $256(64.2 \%)$ belonged to $<1 \mathrm{~km}^{2}$ patch size category. The number of $<1 \mathrm{~km}^{2}$ patches was $493,552,569$, and 576 in 1973, 1990, 2004 and 2013, respectively. Patches of $>100 \mathrm{~km}^{2}$ contributed to highest forest area of $3439 \mathrm{~km}^{2}$ in 1932, while it was $1503 \mathrm{~km}^{2}$ in 2013 (Table 5). The total number of forest patches increased from 398 in 1932 to 702 in 2013 (Table 6). Patch density increased from 6.4 to 6.7 per $\mathrm{km}^{2}$ during 1930-2011. The mean patch size of forest varied across time periods. The mean patch size showed a severe reduction in area of $111 \mathrm{~km}^{2}$ in 1932 to $97.4 \mathrm{~km}^{2}$ in $1973,89.1$ $\mathrm{km}^{2}$ in $1990,89.3 \mathrm{~km}^{2}$ in 2004 and reached to $65.8 \mathrm{~km}^{2}$ by 2013. Largest patch index of forest landscape in 1932 was estimated at $28.5 \%$, whereas $7.3 \%$ of the forest area was concentrated in a single large patch in 2011.

The deforestation rate was also clearly visible from the forest matrix analysis. There was an extensive increase of number of forest patches from 1932 to 1990 . Clearing of forest to adjust population pressure and construction of some water reservoirs were the main reasons. The increase of small sized patches and decrease of bigger forest patches over time was a 
Table 4 : Size class distribution of forest patches and its changes from 1932 to 2013 in Koraput district

\begin{tabular}{lllllllllll}
\hline \multirow{2}{*}{ Patch class $\left(\mathbf{k m}^{2}\right)$} & \multicolumn{3}{c}{1932} & \multicolumn{2}{c}{1973} & \multicolumn{2}{c}{1990} & \multicolumn{2}{c}{2004} & 2013 \\
\cline { 2 - 10 } & Count & $\%$ & Count & $\%$ & Count & $\%$ & Count & $\%$ & Count & $\%$ \\
\hline$<1$ & 256 & 64.2 & 493 & 76.5 & 552 & 80.2 & 569 & 81.7 & 576 & 82 \\
$1-5$ & 62 & 15.7 & 69 & 10.7 & 61 & 8.8 & 57 & 8.2 & 57 & 8.1 \\
$5-10$ & 33 & 8.4 & 47 & 7.3 & 45 & 6.6 & 45 & 6.4 & 45 & 6.4 \\
$10-20$ & 23 & 5.8 & 20 & 3.1 & 17 & 2.5 & 15 & 2.1 & 13 & 1.9 \\
$20-50$ & 14 & 3.4 & 8 & 1.2 & 6 & 0.9 & 5 & 0.7 & 5 & 0.7 \\
$50-100$ & 5 & 1.3 & 3 & 0.5 & 3 & 0.4 & 3 & 0.4 & 3 \\
$>100$ & 5 & 1.2 & 5 & 0.7 & 4 & 0.6 & 3 & 0.5 & 4 & 0.4 \\
Total & 398 & 100 & 645 & 100 & 688 & 100 & 697 & 100 & 702 & 100 \\
\hline
\end{tabular}

Table 5 : Area wise $\left(\mathrm{km}^{2}\right)$ and temporal change of forest patches from 1932 to 2013 in Koraput district

\begin{tabular}{lllllllllll}
\hline \multirow{2}{*}{ Patch class $\left(\mathbf{k m}^{2}\right)$} & \multicolumn{2}{c}{1932} & \multicolumn{2}{c}{1973} & \multicolumn{2}{c}{1990} & \multicolumn{2}{c}{$\mathbf{2 0 0 4}$} & \multicolumn{2}{c}{$\mathbf{2 0 1 3}$} \\
\cline { 2 - 10 } & Area & $\%$ & Area & $\%$ & Area & $\%$ & Area & $\%$ & Area & $\%$ \\
\hline$<1$ & 49 & 1.1 & 52 & 1.4 & 122 & 4.2 & 103 & 4.5 & 106 & 4.9 \\
$1-5$ & 84 & 1.9 & 100 & 2.7 & 119 & 4.1 & 112 & 4.9 & 112 & 5.2 \\
$5-10$ & 124 & 2.8 & 122 & 3.3 & 102 & 3.5 & 85 & 3.7 & 82 & 3.8 \\
$10-20$ & 181 & 4.1 & 163 & 4.4 & 131 & 4.5 & 94 & 4.1 & 89 & 4.1 \\
$20-50$ & 247 & 5.6 & 204 & 5.5 & 160 & 5.5 & 116 & 5.1 & 112 & 5.2 \\
$50-100$ & 291 & 6.6 & 233 & 6.3 & 209 & 7.2 & 167 & 7.3 & 155 & 7.2 \\
$>100$ & 3439 & 77.9 & 2831 & 76.4 & 2060 & 71 & 1608 & 70.4 & 1503 & 69.6 \\
Total & 4414 & 100 & 3706 & 100 & 2901 & 100 & 2284 & 100 & 2159 & 100 \\
\hline
\end{tabular}

Table 6 : Different forest fragmentation indices and their temporal change from 1932 to 2013 in Koraput district

\begin{tabular}{llllll}
\hline Landscape matrices & 1932 & 1973 & $\mathbf{1 9 9 0}$ & $\mathbf{2 0 0 4}$ & $\mathbf{2 0 1 3}$ \\
\hline Number of patches & 398 & 645 & 688 & 697 & 702 \\
Patch density $\left(\right.$ per km $\left.{ }^{2}\right)$ & 6.4 & 10.7 & 5.7 & 6.8 & 6.7 \\
Mean patch size $\left(\mathrm{km}^{2}\right)$ & 111.0 & 97.4 & 89.1 & 89.3 & 65.8 \\
Largest patch $(\%)$ & 28.5 & 15.2 & 7.6 & 7.8 & 7.3 \\
\hline
\end{tabular}

clear indication of anthropogenic pressure on forest, lead to its fragmentation. It is evident that there has been extensive decline in the size of the largest forest patches due to deforestation. Large-scale deforestation in Koraput has led to a decline in forest patch area and increase in the number of patches.

The deforestation rate over eight decades was studied using both topographical sheets and satellite images. This clearly revealed the magnitude of deforestation in Koraput. If such massive levels of deforestation remain unchecked, there is a chance that the district will retain a little forest cover in near future. This will ultimately lead to biodiversity loss. Comprehensive spatial analysis about the status of forests is useful in formulating the policies related to sustainable use and biodiversity conservation. The change and landscape matrix analysis of deforestation provides a decisive component for conservation and helpful in long term rational management of the remaining forests of the district.

\section{Acknowledgments}

The authors thank the Director, ICAR-IISWC, Dehradun for providing facilities and encouragement. We also thank ICARIISWC for financial support.

\section{References}

Adhikary, P.P., H.C. Hombegowda, D. Barman, P. Jakhar and M. Madhu: Soil erosion control and carbon sequestration in shifting cultivated degraded highlands of eastern India: performance of two contour hedgerow systems. Agroforest. Syst., 91, 757-771 (2017). 
Adhikary, P.P., M. Madhu, Ch.J. Dash, D.C.Sahoo, P. Jakhar, B.S. Naik, H.C. Hombegowda, G.B. Naik and B. Dash : Prioritization of traditional tribal field crops based on RWUE in Koraput district of Odisha. Ind. J. Tradit. Knowl., 14, 88-95 (2015).

Armenteras, D., G. Rudas, N. Rodriguez, S. Sua and M. Romero : Pattern and cause of deforestation in Columbian Amazon. Ecol. Indic., 6, 353-368 (2006).

Dash, B. : Shifting cultivation amongst the Tribes of Odisha. Odisha Review. http:// Odishagov.nic.in/e-magazine/ Odishareview/ july2006/ engpdf/76-84.pdf, (Assessed on 30-11-2014) (2006).

ERDAS: ERDAS imagine professional: Tour Guides. Norcross, GA: Leica Geosystems Geospatial Imaging, LLC (2008).

FAO: Global forest resources assessment 2010-Main report. FAO Forestry Paper No. 163, Food and Agriculture Organisation of the United Nations, Rome (2010).

FAO: State of the world's forests, Food and Agriculture Organisation of the United Nations, Rome (2012).

FSI: India State of Forest Report. Forest Survey of India, Ministry of Environment and Forests (MoEF), Government of India (Gol) (1988).

FSI: India State of Forest Report. Forest Survey of India, Ministry of Environment and Forests (MoEF), Government of India (Gol) (2000).

FSI: India State of Forest Report. Forest Survey of India, Ministry of Environment and Forests (MoEF), Government of India (Gol) (2013).

Harikrishna, P., K.R.L. Saranya, C.S. Reddy, C.S. Jha and V.K. Dadhwal: Assessment and monitoring of deforestation from 1930's to 2011 in Andhra Pradesh, India using remote sensing and collateral data. Cur. Sci., 107, 867-875(2014).

IIRS: Biodiversity characterization at landscape level in Andamans and Nikobar islands using satellite remote sensing and geographic information systems. Indian Institute of Remote Sensing. National Remote Sensing Agency, Department of Space, Government of India. Dehra Dun (2002).

Jha, C.S., C.B.S. Dutt and K.S. Bawa: Deforestation and land use changes in Western Ghats, India. Cur. Sci., 79, 231-238 (2000).

Krishnaswamy, J., M.C. Kiran and K.N. Ganeshaiah: Tree model based eco-climatic vegetation classification and fuzzy mapping in diverse tropical deciduous ecosystems using multi-season NDVI. Int. J. Remote Sensing, 25, 1185-1205(2004).

Kumar, G.R.P., A.M. Hemanjali, P. Ravikumar, R.K. Somashekar and B.C. Nagaraja: Assessment of forest encroachment in Belgaum district of Western Ghats of Karnataka using remote sensing and GIS. J. Environ. Biol., 35, 259-264 (2014).

Kumar, P., M. Rani, P.C. Pandey, A. Majumdar and M.S. Nathawat: Monitoring of deforestation and forest degradation using remote sensing and GIS : A case study of Ranchi in Jharkhand (India). Report Opinion, 2, 14-20 (2010).
Lele, N. and P.K. Joshi: Analyzing deforestation rates, spatial forest cover changes and identifying critical areas of forest cover changes in North-East India during 1972-1999. Environ. Monit. Assess., 156, 159-170 (2009).

NBSSLUP: Soil series of Orissa. Technical Bulletin No-119, National Bureau of Soil Survey and Landuse Planning, Nagpur, Maharashtra, India (2005).

Panigrahy, R.K., M.P. Kale, U. Dutta, A. Mishra, B. Banerjee and S. Singh: Forest cover change detection of Western Ghats of Maharashtra using satellite remote sensing based visual interpretation technique. Cur. Sci., 98, 657-664 (2010).

Pattanaik, C., C.S. Reddy and P.M. Reddy: Assessment of spatial and temporal dynamics of forest cover in Malkangiri district of Orissa, India. J. Geograph. Sci., 21, 176-192 (2011).

Raut, S., S.K. Sen, S. Satpathy and D. Pattnaik : An ethno-botanical survey of medicinal plants in Semiliguda of Koraput District, Odisha, India. Bot. Res. Int., 5, 97-107 (2012).

Reddy, C.S., C.S. Jha and V.K. Dadhwal: Assessment and monitoring of long- term forest cover changes in Odisha, India using remote sensing and GIS. Environ. Monit. Assess., 185, 4399-4415 (2013a).

Reddy, C.S., C.S. Jha and V.K. Dadhwal: Spatial dynamics of deforestation and forest fragmentation (1930-2013) in Eastern Ghats, India. Int. Arc. Photogram. Rem. Sens. Spati. Infor. Scien., XL, 637-644 (2014).

Reddy, C.S., K. Dutta and C.S. Jha: Analysing the gross and net deforestation rates in India. Cur. Sci., 105, 1492-1500 (2013b).

Reddy, C.S., P.R.M. Rao, C. Pattanaik and P.K. Joshi: Assessment of large-scale deforestation in Nawarangpur district, Orissa, India : A remote sensing based study. Environ. Monit. Assess., 154, 325335 (2009).

Reddy, C.S., U. Prachi, B. Shilpa, A. Giriraj and S. Sudhakar: Assessment of fragmentation and disturbance patterns in Eastern Ghats: A case study in R.V. Nagar Range, Visakhapatnam district, Andhra Pradesh, India. J. Ind. Soc. Rem. Sensi., 38, 632-639 (2010).

Roy, P.S. and P.K. Joshi: Forest cover assessment in north-east Indiathe potential of temporal wide swath satellite sensor data (IRS-1C WiFS). Int. J. Rem. Sensi., 23, 4881-4896 (2002).

Sakthivel, R., M. Manivel, N.J. Raj, V. Pugalanthi, N. Ravichandran and V.D. Anand: Remote sensing and GIS based forest cover change detection study in Kalrayan hills, Tamil Nadu. J. Environ. Biol., 31, 737-747 (2010).

Satish, K.V., K.R.L. Saranya, C.S. Reddy, P. Hari Krishna, C.S. Jha and P.V.V. Prasada Rao: Geospatial assessment and monitoring of historical forest cover changes (1920-2012) in Nilgiri Biosphere Reserve, Western Ghats, India. Environ. Monit. Assess., 186, 8125 - 8140 (2014). 